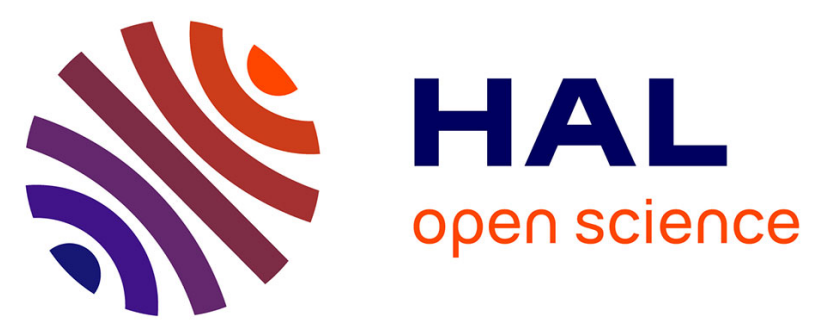

\title{
Assessment of Peak Inspiratory Flow in Young Infants with Acute Viral Bronchiolitis: Physiological Basis for Initial Flow Setting in Patients Supported with High-Flow Nasal Cannula
}

Christophe Milési, Anne Requirand, Aymeric Douillard, Julien Baleine, Erika Nogué, Stefan Matecki, Pascal Amedro, Marti Pons-Odena, Gilles Cambonie

\section{To cite this version:}

Christophe Milési, Anne Requirand, Aymeric Douillard, Julien Baleine, Erika Nogué, et al.. Assessment of Peak Inspiratory Flow in Young Infants with Acute Viral Bronchiolitis: Physiological Basis for Initial Flow Setting in Patients Supported with High-Flow Nasal Cannula. The Journal of Pediatrics, 2020, 231, pp.239-245. 10.1016/j.jpeds.2020.12.020 . hal-03084123

HAL Id: hal-03084123

https://hal.science/hal-03084123

Submitted on 29 Jul 2021

HAL is a multi-disciplinary open access archive for the deposit and dissemination of scientific research documents, whether they are published or not. The documents may come from teaching and research institutions in France or abroad, or from public or private research centers.
L'archive ouverte pluridisciplinaire HAL, est destinée au dépôt et à la diffusion de documents scientifiques de niveau recherche, publiés ou non, émanant des établissements d'enseignement et de recherche français ou étrangers, des laboratoires publics ou privés. 


\title{
Assessment of Peak Inspiratory Flow in Young Infants with Acute Viral Bronchiolitis: Physiological Basis for Initial Flow Setting in Patients Supported with High-Flow Nasal Cannula
}

\author{
Christophe Milési, $\mathrm{MD}^{1}$, Anne Requirand, $\mathrm{GN}^{2}$, Aymeric Douillard, $\mathrm{PhD}^{3}$, Julien Baleine, $\mathrm{MD}^{1}$, Erika Nogué, $\mathrm{MS}^{3}$,
} Stephan Matecki, MD, $\mathrm{PhD}^{2,4}$, Pascal Amedro, MD, $\mathrm{PhD}^{4,5}$, Marti Pons-Odena, MD, $\mathrm{PhD}^{6}$, and Gilles Cambonie, $\mathrm{MD}, \mathrm{PhD}^{1,7}$

Objective To assess the inspiratory demand in young infants with acute viral bronchiolitis to provide a physiological basis for initial flow setting for patients supported with high flow nasal cannula.

Study design Prospective study in 44 infants up to 6 months old with acute viral bronchiolitis, admitted to a pediatric intensive care unit from November 2017 to March 2019. Airflow measurements were performed using spirometry. The primary endpoint was the inspiratory demand as measured by peak tidal inspiratory flow (PTIF). The secondary endpoints were the relationships determined between PTIF, patient weight, and disease severity. Results Median $\left(Q_{25}-Q_{75}\right)$ age and weight of the patients were $37(20-67)$ days and $4.3(3.5-5.0) \mathrm{kg}$, respectively. Mean PTIF was 7.45 (95\% Cl 6.51-8.39, min-max: $2.40-16.00) \mathrm{L} /$ minute. PTIF indexed to weight was $1.68(95 \% \mathrm{Cl}$ 1.51-1.85, min-max: 0.67-3.00) L/kg/minute. PTIF was $<2.5 \mathrm{~L} / \mathrm{kg} /$ minute in $89 \%(95 \% \mathrm{Cl} 75-96)$ of infants. PTIF was correlated with weight $(\rho=0.55, P<.001)$ but not with markers of disease severity, including modified Woods clinical asthma score, Silverman-Andersen score, respiratory rate, fraction of inspired oxygen, and $\mathrm{PCO}_{2}$.

Conclusions High flow nasal cannula therapy is used commonly to support infants with acute viral bronchiolitis. The efficiency of the device is optimal if the flow setting matches the patient's inspiratory demand. According to our results, a flow rate of $<2.5 \mathrm{~L} / \mathrm{kg} /$ minute would be appropriate in most situations.

cute viral bronchiolitis is the most common respiratory infection in infancy and a public health concern, accounting for the hospitalization of $2 \%-3 \%$ of all children younger than 12 months every year. ${ }^{1,2}$ Although most cases respond to supportive care only, $9 \%-22 \%$ of the patients with moderate to severe forms require admission to a pediatric intensive care unit (PICU). ${ }^{3-6}$ Noninvasive ventilation, with nasal continuous positive airway pressure (nCPAP) or high-flow nasal cannula oxygen therapy (HFNC), is currently used as the first-line respiratory support to reduce the risk of intubation. ${ }^{7,8}$

HFNC has become increasingly popular in PICUs, as caregivers perceive it to be more easily set up and better tolerated than nCPAP. ${ }^{9}$ For acute viral bronchiolitis, studies have suggested promising outcomes on both physiological ${ }^{10,11}$ and clinical $^{12,13}$ grounds. However, worsening respiratory failure or severe apnea may occur despite this technique, leading to an escalation in therapeutic measures. Failure rates vary widely, from $10 \%$ to $50 \%$ in key randomized controlled studies, ${ }^{3,4,14}$ and are notably dependent on population characteristics, particularly age and comorbidities, disease severity, the device allocated to the control group, and the criteria and delay in defining failure. ${ }^{15}$

HFNC efficacy in cases of respiratory failure is conditioned by several mecanisms. ${ }^{16}$ Among them, matching the HFNC flow rate to the patient's inspiratory demand and/or degree of respiratory distress is necessary to ensure consistency in oxygen delivery and facilitate inspiration. ${ }^{17}$ Inspiratory demand can be measured by the patient's peak tidal inspiratory flow (PTIF). PTIF values in infants with acute viral bronchiolitis have never been assessed. The primary objective of this physiological study was to measure PTIF values in young infants with moderate acute viral bronchiolitis. The secondary objective was to

$\begin{array}{ll}\mathrm{EEL} & \text { End-expiratory level } \\ \mathrm{FiO}_{2} & \text { Fraction of inspired oxygen } \\ \mathrm{HFNC} & \text { High-flow nasal cannula } \\ \mathrm{HR} & \text { Heart rate } \\ \text { m-WCAS } & \text { Modified Woods clinical asthma score } \\ \text { nCPAP } & \text { Nasal continuous positive airway pressure } \\ \mathrm{PICU} & \text { Pediatric intensive care unit } \\ \text { PTIF } & \text { Peak tidal inspiratory flow } \\ \text { RR } & \text { Respiratory rate } \\ \text { TV } & \text { Tidal volume }\end{array}$

From the ${ }^{1}$ Pediatric Intensive Care Unit, Arnaud de Villeneuve Hospital, Montpellier University Hospital Centre, Montpellier, France; ${ }^{2}$ Pediatric Functional Exploration Unit, Arnaud de Villeneuve Hospital, Montpellier University Hospital Center, Montpellier. France; ${ }^{3}$ Department of Medical Information, Montpellier University Hospital Center, Montpellier, France; ${ }^{4}$ PHYMEDEXX, CNRS UMR 9214, INSERM U1046,
PHE University of Montpellier, Montpellier, France; ${ }^{5}$ Pediatric Cardiology and Pulmonology Department, M3C Regional Reference Center, Arnaud de Villeneuve Hospital, Montpellier University Hospital Center, Montpellier, France; ${ }^{6}$ Pediatric Intensive Care Unit, Sant Joan de Deu University Hospital Center, University of Barcelona, Esplugues de Llobregat, Barcelona, Spain; and ${ }^{7}$ Pathogenesis and Control of Chronic Infection, INSERM UMR 1058, University of Montpellier, Montpellier, France The authors declare no conflicts of interest. 
investigate the potential relationships between PTIF values, patient weight, and disease severity.

\section{Methods}

This prospective observational study was conducted in an 8-bed PICU at Montpellier University Hospital Center.

\section{Population}

All infants less than 6 months old and hospitalized in the PICU were considered for inclusion, provided that the following conditions were met: (1) clinical diagnosis of bronchiolitis based on medical history and physical examination ${ }^{18}$; (2) moderate respiratory distress, defined using the modified Woods clinical asthma score (m-WCAS $)^{19}$ as $2 \leq \mathrm{m}$-WCAS $\leq 5$; (3) respiratory support with HFNC; and (4) authorization to perform the study signed by both parents.

Patients were ineligible if there was an indication for immediate intubation for invasive ventilation; the subject was already being treated with nCPAP on admission to the PICU; and the presence of heart disease, cystic fibrosis, or neuromuscular disorder.

\section{Study Protocol}

On admission, the nurse cleared nasopharyngeal secretions and, according to the PICU's protocol for patients with moderate bronchiolitis, placed the nasal cannulae (Airvo 2 or Optiflow, Fisher and Paykel) with a flow rate set at $2 \mathrm{~L} / \mathrm{kg} /$ minute. Fraction of inspired oxygen $\left(\mathrm{FiO}_{2}\right)$ was titrated to target $\mathrm{SpO}_{2}$ between $94 \%$ and $97 \%$.

Within 24 hours of admission and after verification of eligibility and parental consent for study inclusion, the physiologist recorded the spirometric data while blind from clinical parameters. The cardiorespiratory monitor (IntelliVue MP70, Philips Medical Systems) was set on "Visitor" mode to hide patient's data from the physiologist during recording. Heart rate (HR), respiratory rate (RR), m-WCAS, SilvermanAndersen retraction score, $\mathrm{FiO}_{2}$, and $\mathrm{SpO}_{2}$ were collected in the hour immediately preceding the spirometric measurements in patients breathing spontaneously with low oxygen flow $(<2 \mathrm{~L} /$ minute).

\section{Spirometry}

The patients were disconnected from the nasal cannulae at least 5 minutes before measurement to allow them to adjust with the new equipment and obtain a calm state. A soft transparent mask adapted to each infant's size (Ambu King Mask, size 1) was applied gently on the face, covering the nose and mouth. A mixture of air/oxygen was provided through a large volume balloon and a T-piece to reach the target $\mathrm{SpO}_{2}$. The flow rate was reduced to $2 \mathrm{~L} /$ minute before measurements, with a balloon in the semifilled state (Figure 1). The flowmeter was then calibrated with a 100-mL pump and the same mixture of air/oxygen. Calibration was accepted if the margin of error between the volume injected and the volume measured was less than $5 \%$.

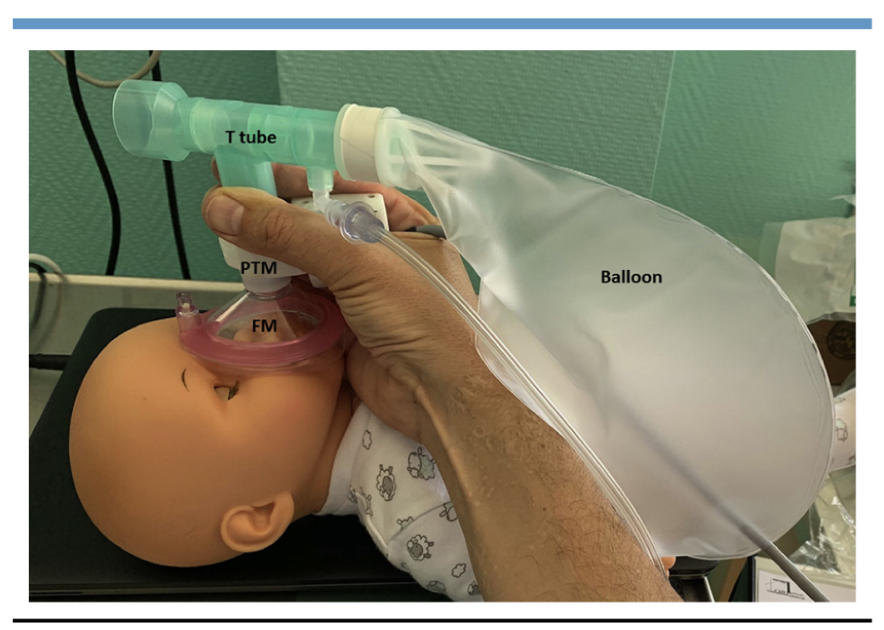

Figure 1. Tidal breathing measurements in an infant. A soft transparent face mask ( $F M)$ enclosed the nose and mouth. Air/oxygen mixture $(2 \mathrm{~L} /$ minute) was provided through a large volume balloon and a T-piece. Calibration of the pneumotachometer (PTM) and a leak test were performed before measurements.

During measurement recording, the operator visually ensured the absence of drift in the baseline flow signal, the absence of artifacts, and the reproducibility of loops. A straight ruler was placed on the monitor screen showing the instantaneous graphic representation of tidal volume (TV) as a function of time to ensure that all of the lowest points at each end of expiration could be linked by a virtual horizontal line. On the flow/volume loops, the operator visually checked that all curves wrapped continuously around themselves. A leak test to ensure the stability of the endexpiratory level (EEL) was subsequently performed by sealing the external orifice of the pneumotachometer with the thumb for a brief period during expiration. EEL stability was confirmed by variation less than 3\% of the TV over 5-10 cycles surrounding the manual occlusion.

In each infant, at least 10 consecutive reproducible respiratory cycles (ie, with a variation coefficient of the respiratory parameters $<10 \%$ ) were selected and averaged for data analysis. ${ }^{20}$ Inspiratory time, expiratory time, RR, TV, and PTIF were measured using a pneumotachometer (Jaeger Spirometer, size S). The airway flow and TV signals were digitalized and recorded at $200 \mathrm{~Hz}$ using a respiratory physiologic recording program (Jaeger MasterScreen-Paed).

To answer the research question pragmatically about the optimal flow rate setting of an HFNC device for infants with moderate acute viral bronchiolitis, PTIF values measured as $\mathrm{ml} / \mathrm{s}$ were expressed as $\mathrm{L} /$ minute.

\section{Scales and Scores}

The m-WCAS is a composite score comprising 5 components (cyanosis, inspiratory breath sounds, accessory muscle use, expiratory wheezing, and cerebral function) to assess the severity of bronchiolitis, with a visual analog scale to 
standardize the scoring of accessory muscle use and wheezing. ${ }^{21}$ The maximum score is 2 for each component and 10 for the composite score.

The Silverman-Andersen score also has 5 components to describe the intensity of retraction in neonates. ${ }^{22}$ The score is computed by adding the values $(0,1$, or 2$)$ assigned to each criterion, with 0 indicating no retraction and 10 maximal retraction.

\section{Outcomes}

The primary outcome was the spontaneous PTIF value, based on the average of 10 consecutive measures.

Prespecified secondary outcomes were the rate of patients with weight-indexed PTIF higher than $2 \mathrm{~L} / \mathrm{kg} /$ minute and the correlations between crude PTIF and weight, and between PTIF (crude or indexed to weight) and the following markers of respiratory distress severity: HR, RR, m-WCAS, Silverman-Andersen retraction score, $\mathrm{FiO}_{2}$, and $\mathrm{PCO}_{2}$.

Tertiary outcomes (analyses of which were considered to be hypothesis-generating) included intubation, requirement of noninvasive ventilation, duration of respiratory support, length of stay in the PICU, and their respective relationships with the spirometric data. According to our protocol, noninvasive ventilation was considered for infants with worsening respiratory distress, defined by $\mathrm{m}-\mathrm{WCAS}>5$ and/or RR rise $>10$ rpm. $^{14}$

\section{Statistical Analyses}

Sample size calculation was based on the accuracy of weightindexed PTIF estimation, taking into account an expected mean value of $2 \mathrm{~L} / \mathrm{kg} /$ minute and a SD of 1 . On this assumption and to reach a $95 \% \mathrm{CI}$ of $0.6 \mathrm{~L} / \mathrm{kg} /$ minute, taken to be sufficiently accurate, at least 43 children had to be recruited. To anticipate the failure of the respiratory parameter recordings, this number was increased by $15 \%$ and upgraded to 50 .

Categorical variables were expressed in numbers and percentages. For the quantitative variables, normal distribution was assessed using the Shapiro-Wilk test. PTIF and weightindexed PTIF were normally distributed and were described using means and 95\% CI and extreme values (min-max). For others continuous variables, not all were found to be normally distributed, and results were shown as medians with IQR (Q25-Q75). Correlations between variables were estimated with Pearson (r) or Spearman $(\rho)$ correlation coefficients as appropriate. Comparisons between infants requiring invasive or noninvasive ventilation (this last defined as the use of nCPAP and/or bilevel positive airway pressure) and infants exclusively supported with HFNC were performed using the Student $t$ test or the MannWhitney test as appropriate. A $P$ value of $<.05$ was considered statistically significant. Statistical analysis was conducted using SAS Enterprise Guide 7.13 (SAS Institute).

\section{Ethical Considerations}

The study protocol was approved by the West VI Ethics Committee (decision CPP 1020-HPS2, on the 2017/11/02). This study was recorded on the National Library of Medicine registry (NCT03298217). Signed consent was obtained from the 2 parents of all infants.

\section{Results}

From November 2017 to March 2019, 141 infants $\leq 6$ months of age were admitted to the department for acute viral bronchiolitis; 63 patients were eligible. In 11 cases, admission to the PICU occurred on a public holiday and spirometric evaluation was impossible within 24 hours (parents not approached). In 2 cases, the parents declined to give consent (Figure 2). Spirometric measurements were performed in 50 patients. The data of 6 patients were not usable due to leaks around the mask. The postnatal age and weight of the 44 patients with available spirometric measurements were 37 (20-67) days and $4.3(3.5-5.0) \mathrm{kg}$, respectively. Sex ratio indicated a majority of male patients (55\%). Only 1 infant was born before 37 weeks of gestation. Respiratory syncytial virus was found in 35 patients $(80 \%)$. Overall clinical characteristics, according to the data collected before spirometry, were consistent with a moderate form of the disease (Table I).

\section{Primary Endpoint}

Mean PTIF was 7.45 (95\% CI 6.51-8.39, min-max 2.4016.00) $\mathrm{L} /$ minute. Indexed to weight, the mean value was 1.68 (95\% CI 1.51-1.85, min-max 0.67-3.00) L/kg/minute. Weight-indexed PTIF was $<1 \mathrm{~L} / \mathrm{kg} /$ minute for $14 \%(95 \%$ CI 6-28) of patients $(6 / 44), 1-1.5 \mathrm{~L} / \mathrm{kg} /$ minute for $27 \%$ (95\% CI 15-43) of patients (12 of 44 ), $1.5-2 \mathrm{~L} / \mathrm{kg} /$ minute for $30 \%(95 \%$ CI $17-45)$ of patients (13 of 44$), 2-2.5 \mathrm{~L} / \mathrm{kg} /$ min for $18 \%$ (95\% CI 9-33) of patients (8 of 44), and $>2.5 \mathrm{~L} / \mathrm{kg} / \mathrm{min}$ for $11 \%$ (95\% CI $4-25$ ) (5 of 44 ).

\section{Secondary Endpoints}

Spirometry. The other measurements recorded during spirometry are indicated on Figure 3. A significant correlation $(\rho=0.55, P<.001)$ was found between PTIF and patient weight. No correlation was observed between PTIF, whether crude or weight-indexed, and the markers of respiratory distress severity: HR, RR, m-WCAS, SilvermanAndersen retraction score, $\mathrm{FiO}_{2}, \mathrm{PCO}_{2}$, duration of overall respiratory support, and length of stay in the PICU (Table II; available at www.jpeds.com).

Patient Outcome. Respiratory support with HFNC was provided for 3 (1.5-4) days. One infant was intubated, and 16 $(36 \%)$, including the patient who was intubated, required noninvasive ventilation for a duration of 2 (1-3) days. The duration of overall respiratory support, including HFNC, noninvasive ventilation, and invasive ventilation, was 3.5 (2.5-5.0) days. The weight of these 16 infants was lower than that of the rest of the cohort $(P=.02)$, but no other difference was observed in clinical characteristics and spirometric values, including PTIF (Table III; available at www.jpeds.com). The length of stay in the PICU was 4.5 (3-6.5) days. 


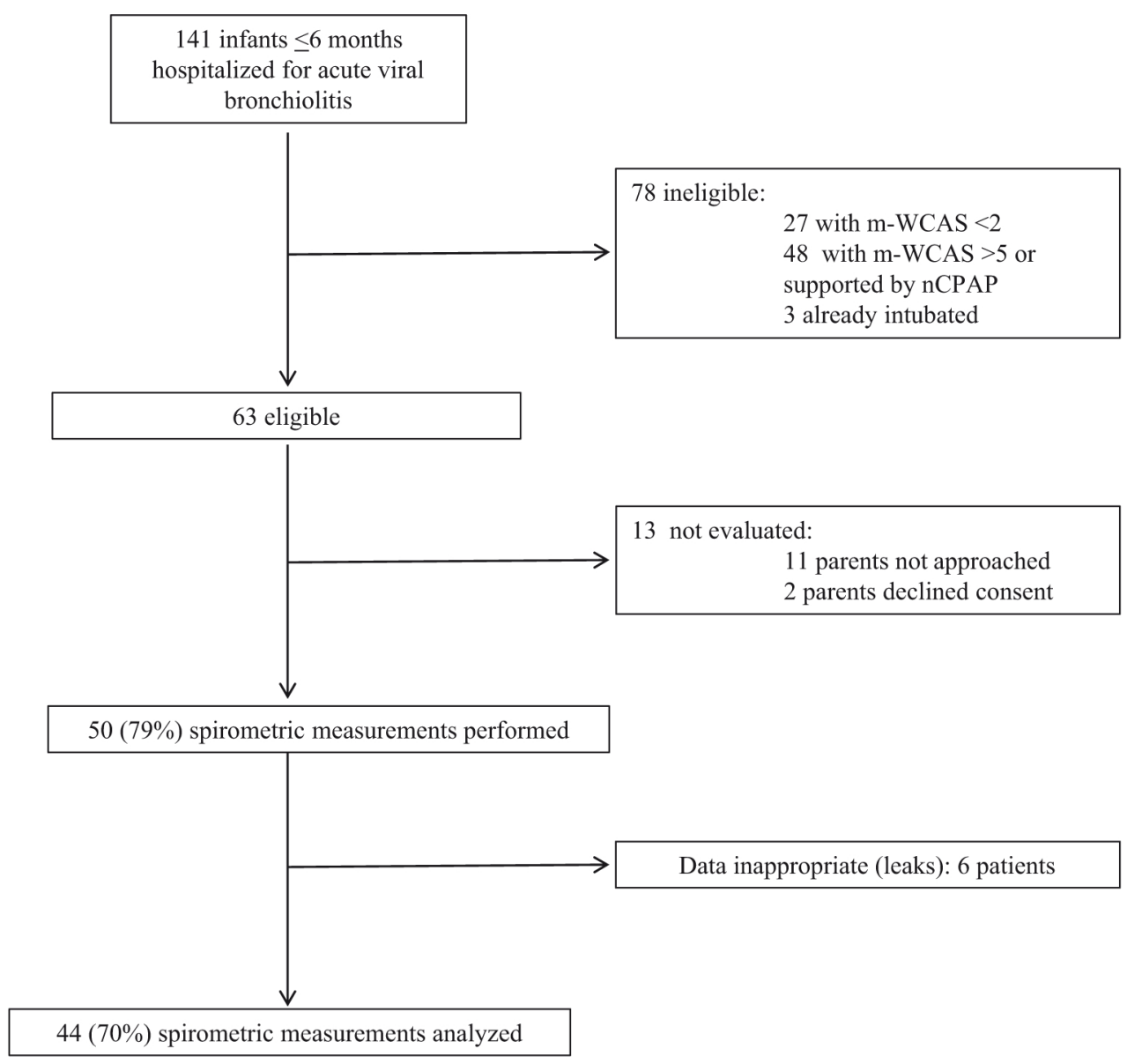

Figure 2. Flowchart of the study population.

\section{Discussion}

PTIF measurements were used to calculate a mean inspiratory demand at $1.68(0.56) \mathrm{L} / \mathrm{kg} /$ minute in infants 6 months old or less with moderate acute viral bronchiolitis. PTIF was $<2.5 \mathrm{~L} / \mathrm{kg} /$ minute in nearly $90 \%$ of patients. No correlation was found between PTIF and the markers of severity of acute viral bronchiolitis.

Information on respiratory function remains limited for infants in the PICU, whereas assessment of respiratory

Table I. Clinical characteristics of patients $(N=44)$

\begin{tabular}{lc}
\hline & Median $\left(\mathbf{Q}_{25}-\mathbf{Q}_{75}\right)$ \\
\hline $\mathrm{RR}($ breath/min) & $66(50-78)$ \\
$\mathrm{HR}($ beat/min) & $154(140-162)$ \\
$\mathrm{SpO}_{2}(\%)$ & $95(92-97)$ \\
$\mathrm{FiO}_{2}(\%)$ & $22.5(21-30)$ \\
$\mathrm{m}-\mathrm{WCAS}$ & $2.5(2.0-3.0)$ \\
$\mathrm{Silverman}-$ Andersen score & $2(2-4)$ \\
$\mathrm{pH}$ & $7.37(7.30-7.40)$ \\
$\mathrm{PCO}_{2}(\mathrm{~mm} \mathrm{Hg})$ & $48(43-57)$ \\
\hline
\end{tabular}

Data collected in patients breathing spontaneously with low oxygen flow $(<2 \mathrm{~L} / \mathrm{min})$. mechanics at bedside may impact patient management. ${ }^{23}$ Airflow measurement at the airway opening remains the gold standard for precise ventilatory measurements. ${ }^{24}$ Lung function testing in infants with acute viral bronchiolitis has mainly focused on expiratory flow, with the aim of testing the efficacy of bronchodilators, alone or in combination with corticosteroids. ${ }^{25}$

The effectiveness of HFNC results in part from the maintenance of positive pharyngeal pressure throughout the respiratory cycle. This pressure, however, may be negative during part or all of inspiration if the HFNC flow rate is lower than the inspiratory demand. ${ }^{10}$ Matching the patient's inspiratory flow rate provides for a washout of nasopharyngeal dead space, which contributes to enhancing oxygen delivery and reducing $\mathrm{CO}_{2}$ rebreathing. ${ }^{26}$ Inspiratory demand can be measured by the patient's PTIF, but the data on PTIF are scarce for young infants, especially those who are sick. In very preterm neonates, Siew et al recorded flows reaching $50 \mathrm{~mL} / \mathrm{kg} / \mathrm{second}$ (ie, $3 \mathrm{~L} / \mathrm{kg} / \mathrm{min}$, in the first 3 minutes of life in the delivery room). ${ }^{27}$ In healthy neonates, Schmalisch et al used an elegant dead space-free flow-through technique and found $0.83(0.2) \mathrm{L} / \mathrm{kg} /$ minute at the end of the first postnatal week. ${ }^{28}$ The same group observed comparable values 


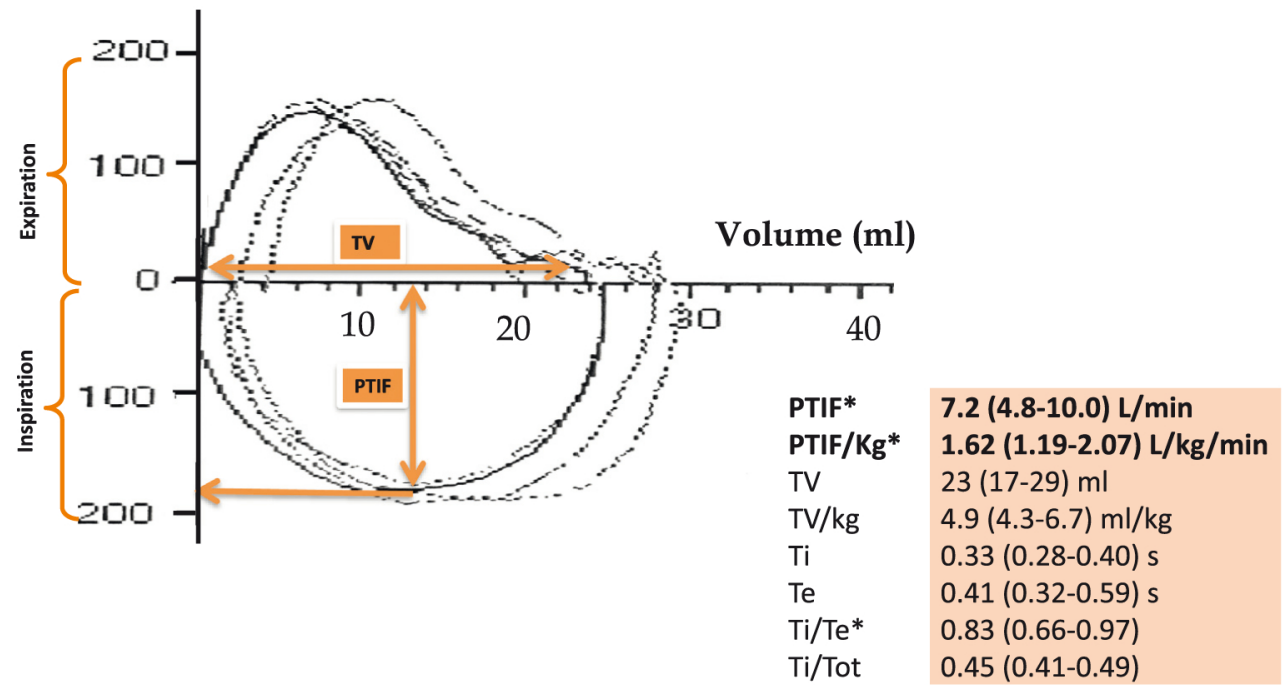

Figure 3. Ongoing flow/volume loops recorded in a single patient. Spirometric values were averaged from 10 consecutive loops. Values are medians with IQR (Q25-Q75) in 44 patients with acute viral bronchiolitis. *Normally distributed variables. Te, expiratory time; Ti, inspiratory time.

during routine follow-up of ex-premature infants at a median postmenstrual age of 48 weeks (ie, approximately 2 months after a theoretical term of 41 weeks). ${ }^{29}$ To our knowledge, no data have been reported in infants with moderate acute viral bronchiolitis, and our measures suggest that PTIF is on average twice that of healthy infants.

A survey conducted in America, Asia, Europe, and Australia/New Zealand revealed significant practice variations in the use of HFNC in infants and children. ${ }^{30}$ According to the opinion of pediatric consultants in the United Kingdom in 2019, HFNC start-up flow rate in cases of acute viral bronchiolitis ranged from 2 to $4 \mathrm{~L} / \mathrm{kg} /$ minute. ${ }^{31}$ Our results showed that $40 \%$ of patients had PTIF values of $<1.5 \mathrm{~L} /$ $\mathrm{kg} /$ minute, indicating that many may require more modest flow rates. Randomized controlled studies have also used wide ranges, from 1 to $3 \mathrm{~L} / \mathrm{kg} /$ minute. ${ }^{15,32,33}$ Determining an optimal flow from these studies is hazardous, especially as they are heterogeneous for both enrolled patient characteristics and judgment criteria. In this regard, an unambiguous endpoint like the need for intubation has almost never been selected, given its low occurrence. Our study provides physiological justification for the flow rate required to compensate for a patient's increased inspiratory demand and for titrating it on the patient's weight ${ }^{34}$ because this last was the sole determinant of the demand. In this regard, none of the severity criteria were correlated with PTIF and, thus, cannot guide the clinician in selecting an adequate flow rate. During spontaneous breathing, PTIF depends primarily on inspiratory muscle strength and respiratory resistance. Excessive chest wall compliance, sometimes still observed at this young age, should also be considered. In premature newborns, management of respiratory distress with nCPAP seems more frequently successful in patients with stiffer chest walls, which may help to generate higher PTIF and TV for comparable inspiratory effort. ${ }^{27}$ These elements might explain why PTIF was not correlated with severity markers, each of which reflects an aspect of the disease, nor associated with patient outcome.

This study provides the physiological basis for setting a flow rate that matches the patient's inspiratory flow. According to our results, $2.5 \mathrm{~L} / \mathrm{kg} /$ minute should be adequate in nearly $90 \%$ of situations when using HFNC to support infants with moderate acute viral bronchiolitis. No clinical or biological data made it possible to distinguish the 5 patients with PTIF above this threshold, and their clinical course was comparable with that of the rest of the cohort (data not shown). In infants and young children, Weiler et al found a dose-dependent relationship between increasing HFNC flow rates and the reductions in the effort of breathing, with optimal flow rates between 1.5 and $2.0 \mathrm{~L} / \mathrm{kg} /$ minute. $^{35}$ These data were consistent with the results of the TRAMONTANE 2 study, which demonstrated that the use of flow rates above $2.0 \mathrm{~L} / \mathrm{kg} /$ minute did not reduce the risk of failure, which was in most cases associated with the worsening of respiratory distress. ${ }^{32} \mathrm{~A}$ higher flow might potentially generate a higher degree of airway distending pressure, given the linear relationship between the flow rate indexed to the patient's weight and the pharyngeal pressure at this value. ${ }^{36}$ Such a strategy could be considered on a case-by-case basis in the presence of a marked work of breathing or severe hypoxemia, indicating a significant shunt effect. ${ }^{37}$

This study included a limited number of patients, although more than in previous physiological studies on this topic. ${ }^{10,11,21,38-40}$ Moreover, our data only apply to moderate acute viral bronchiolitis (ie, the population usually treated with HFNC), and it may, therefore, be appropriate to assess 
the relationship between PTIF and severity markers in a sample that also includes severe acute viral bronchiolitis. Our data are also limited to the initial flow setting (ie, within 24 hours of admission to a PICU) in infants spontaneously breathing. Further studies are thus needed to assess the longitudinal course of PTIF in infants supported with HFNC. Another limitation is the absence of a control group, which could have been justified given the limited data on PTIF in young infants.

Our values were obtained while the patients were breathing with a facemask attached to a pneumotachometer and a T-piece. The main issue with this measurement is the apparatus dead space, which was $<10 \mathrm{~mL}$ with the mask we used. ${ }^{24}$ This dead space is likely to modify the breathing pattern of newborns, especially those born prematurely, due to $\mathrm{CO}_{2}$ rebreathing. A $10 \%-15 \%$ increase in TV and $\mathrm{RR}$ was observed in neonates if respiratory function testing was performed with the conventional technique, as used in our study, compared with the dead space-free flow-through technique developed by Schmalisch et al. ${ }^{24} \mathrm{TV}$ in our population was clearly greater than the mask's dead space, although we acknowledge that the PTIF reported in this study might be slightly higher than that measured in the absence of dead space.

This study showed that PTIF was $<2.5 \mathrm{~L} / \mathrm{kg} /$ minute in nearly $90 \%$ of infants 6 months old or less with moderate acute viral bronchiolitis. A flow rate $>3 \mathrm{~L} / \mathrm{kg} /$ minute, the maximum value of PTIF in our population, should be used cautiously.

Reprint requests: Gilles Cambonie, MD, PhD, Department of Neonatal Medicine and Pediatric Intensive Care, Arnaud de Villeneuve University Hospital, 371 Avenue du Doyen Gaston Giraud, 34295 Montpellier Cedex 5, France. E-mail: g-cambonie@chu-montpellier.fr

\section{References}

1. Welliver RC. Review of epidemiology and clinical risk factors for severe respiratory syncytial virus (RSV) infection. J Pediatr 2003;143:S112-7.

2. Meissner HC. Viral bronchiolitis in children. N Engl J Med 2016;374:6272.

3. Kepreotes E, Whitehead B, Attia J, Oldmeadow C, Collison A, Searles A, et al. High-flow warm humidified oxygen versus standard low-flow nasal cannula oxygen for moderate bronchiolitis (HFWHO RCT): an open, phase 4, randomised controlled trial. Lancet 2017;389:930-9.

4. Franklin D, Babl FE, Schlapbach LJ, Oakley E, Craig S, Neutze J, et al. A randomized trial of high-flow oxygen therapy in infants with bronchiolitis. N Engl J Med 2018;378:1121-31.

5. Schuh S, Kwong JC, Holder L, Graves E, Macdonald EM, Finkelstein Y. Predictors of critical care and mortality in bronchiolitis after emergency department discharge. J Pediatr 2018;199:217-22.e1.

6. Gupta P, Beam BW, Rettiganti M. Temporal trends of respiratory syncytial virus-associated hospital and ICU admissions across the United States. Pediatr Crit Care Med 2016;17:e343-51.

7. Franklin D, Fraser JF, Schibler A. Respiratory support for infants with bronchiolitis, a narrative review of the literature. Paediatr Respir Rev 2019;30:16-24.
8. Essouri S, Baudin F, Chevret L, Vincent M, Emeriaud G, Jouvet P. Variability of care in infants with severe bronchiolitis: less-invasive respiratory management leads to similar outcomes. J Pediatr 2017;188: 156-62.e1.

9. Lee JH, Rehder KJ, Williford L, Cheifetz IM, Turner DA. Use of high flow nasal cannula in critically ill infants, children, and adults: a critical review of the literature. Intensive Care Med 2013;39:247-57.

10. Milési C, Baleine J, Matecki S, Durand S, Combes C, Novais AR, et al. Is treatment with a high flow nasal cannula effective in acute viral bronchiolitis? A physiologic study. Intensive Care Med 2013;39:1088-94.

11. Pham TM, O'Malley L, Mayfield S, Martin S, Schibler A. The effect of high flow nasal cannula therapy on the work of breathing in infants with bronchiolitis. Pediatr Pulmonol 2015;50:713-20.

12. McKiernan C, Chua LC, Visintainer PF, Allen H. High flow nasal cannulae therapy in infants with bronchiolitis. J Pediatr 2010;156:634-8.

13. Schibler A, Pham TM, Dunster KR, Foster K, Barlow A, Gibbons K, et al. Reduced intubation rates for infants after introduction of high-flow nasal prong oxygen delivery. Intensive Care Med 2011;37:847-52.

14. Milési C, Essouri S, Pouyau R, Liet JM, Afanetti M, Portefaix A, et al. High flow nasal cannula (HFNC) versus nasal continuous positive airway pressure (nCPAP) for the initial respiratory management of acute viral bronchiolitis in young infants: a multicenter randomized controlled trial (TRAMONTANE study). Intensive Care Med 2017;43:209-16.

15. Lin J, Zhang Y, Xiong L, Liu S, Gong C, Dai J. High-flow nasal cannula therapy for children with bronchiolitis: a systematic review and metaanalysis. Arch Dis Child 2019;104:564-76.

16. Dysart K, Miller TL, Wolfson MR, Shaffer TH. Research in high flow therapy: mechanisms of action. Respir Med 2009;103:1400-5.

17. Ramnarayan P, Schibler A. Glass half empty or half full? The story of high-flow nasal cannula therapy in critically ill children. Intensive Care Med 2017;43:246-9.

18. Ralston SL, Lieberthal AS, Meissner HC, Alverson BK, Baley JE, Gadomski AM, et al. Clinical practice guideline: the diagnosis, management, and prevention of bronchiolitis. Pediatrics 2014;134:e1474-502.

19. Martinón-Torres F, Rodríguez-Núñez A, Martinón-Sánchez JM. Nasal continuous positive airway pressure with heliox versus air oxygen in infants with acute bronchiolitis: a crossover study. Pediatrics 2008;121: e1190-5.

20. Bates JH, Schmalisch G, Filbrun D, Stocks J. Tidal breath analysis for infant pulmonary function testing. ERS/ATS task force on standards for infant respiratory function testing. European Respiratory Society/ American Thoracic Society. Eur Respir J 2000;16:1180-92.

21. Cambonie G, Milési C, Jaber S, Amsallem F, Barbotte E, Picaud JC, et al. Nasal continuous positive airway pressure decreases respiratory muscles overload in young infants with severe acute viral bronchiolitis. Intensive Care Med 2008;34:1865-72.

22. Silverman WA, Andersen DH. A controlled clinical trial of effects of water mist on obstructive respiratory signs, death rate and necropsy findings among premature infants. Pediatrics 1956;17:1-10.

23. Peterson-Carmichael S, Seddon PC, Cheifetz IM, Frerichs I, Hall GL, Hammer J, et al. An official American Thoracic Society/European Respiratory Society workshop report: evaluation of respiratory mechanics and function in the pediatric and neonatal intensive care units. Ann Am Thorac Soc 2016;13:S1-11.

24. Schmalisch G, Foitzik B, Wauer RR, Stocks J. Effect of apparatus dead space on breathing parameters in newborns: "flow-through" versus conventional techniques. Eur Respir J 2001;17:108-14.

25. Yusuf F, Prayle AP, Yanney MP. $\beta_{2}$-agonists do not work in children under 2 years of age: myth or maxim? Breathe (Sheff) 2019;15:273-6.

26. Frizzola M, Miller TL, Rodriguez ME, Zhu Y, Rojas J, Hesek A, et al. High-flow nasal cannula: impact on oxygenation and ventilation in an acute lung injury model. Pediatr Pulmonol 2011;46:67-74.

27. Siew ML, van Vonderen JJ, Hooper SB, te Pas AB. Very preterm infants failing CPAP show signs of fatigue immediately after birth. PLoS One 2015;10:e0129592. 
28. Schmalisch G, Wilitzki S, Wauer RR. Differences in tidal breathing between infants with chronic lung diseases and healthy controls. BMC Pediatr 2005;5:36.

29. Barikbin P, Sallmon H, Wilitzki S, Photiadis J, Bührer C, Koehne P, et al. Lung function in very low birth weight infants after pharmacological and surgical treatment of patent ductus arteriosus - a retrospective analysis. BMC Pediatr 2017;17:5.

30. Kawaguchi A, Garros D, Joffe A, DeCaen A, Thomas NJ, Schibler A, et al. Variation in practice related to the use of high flow nasal cannula in critically ill children. Pediatr Crit Care Med 2020;21:e228-35.

31. Hosheh O, Edwards CT, Ramnarayan P. A nationwide survey on the use of heated humidified high flow oxygen therapy on the paediatric wards in the UK: current practice and research priorities. BMC Pediatr 2020;20: 109.

32. Milési C, Pierre AF, Deho A, Pouyau R, Liet JM, Guillot C, et al. A multicenter randomized controlled trial of a $3-\mathrm{L} / \mathrm{kg} / \mathrm{min}$ versus $2-\mathrm{L} / \mathrm{kg} / \mathrm{min}$ high-flow nasal cannula flow rate in young infants with severe viral bronchiolitis (TRAMONTANE 2). Intensive Care Med 2018;44:1870-8.

33. Yurtseven A, Turan C, Erseven E, Saz EU. Comparison of heated humidified high-flow nasal cannula flow rates $\left(1-\mathrm{L} \cdot \mathrm{kg} \cdot \mathrm{min}^{-1} \mathrm{vs} 2-\mathrm{L} \cdot \mathrm{kg} \cdot \mathrm{min}^{-1}\right)$ in the management of acute bronchiolitis. Pediatr Pulmonol 2019;54: 894-900.
34. Shein SL, Slain KN, Rotta AT. High flow nasal cannula flow rates: new data worth the weight. J Pediatr 2017;189:9-10.

35. Weiler T, Kamerkar A, Hotz J, Ross PA, Newth CJL, Khemani RG. The relationship between high flow nasal cannula flow rate and effort of breathing in children. J Pediatr 2017;189:66-71.e3.

36. Milési C, Boubal M, Jacquot A, Baleine J, Durand S, Odena MP, et al. High-flow nasal cannula: recommendations for daily practice in pediatrics. Ann Intensive Care 2014 30;4:29.

37. Mauri T, Alban L, Turrini C, Cambiaghi B, Carlesso E, Taccone P, et al. Optimum support by high-flow nasal cannula in acute hypoxemic respiratory failure: effects of increasing flow rates. Intensive Care Med 2017;43:1453-63.

38. Stokes GM, Milner AD, Groggins RC. Work of breathing, intra-thoracic pressure and clinical findings in a group of babies with bronchiolitis. Acta Paediatr Scand 1981;70:689-94.

39. Essouri S, Durand P, Chevret L, Balu L, Devictor D, Fauroux B, et al. Optimal level of nasal continuous positive airway pressure in severe viral bronchiolitis. Intensive Care Med 2011;37:2002-7.

40. Baudin F, Emeriaud G, Essouri S, Beck J, Portefaix A, Javouhey E, et al. Physiological effect of prone position in children with severe bronchiolitis: a randomized cross-over study (BRONCHIO-DV). J Pediatr 2019;205:112-9.e4.

\section{Table II. Relationships between PTIF, crude or indexed to weight, and markers of severity of respiratory distress}

\begin{tabular}{lrrcc} 
& PTIF & $\boldsymbol{P}$ & Weight-indexed PTIF & $\boldsymbol{P}$ \\
\hline $\mathrm{HR}^{*}$ & 0.11 & .47 & 0.26 & .09 \\
$\mathrm{RR}^{*}$ & -0.13 & .38 & 0.14 & .37 \\
$\mathrm{~m}$-WCAS & 0.16 & .31 & 0.02 & .88 \\
$\mathrm{Silverman-Andersen} \mathrm{score}$ & 0.04 & .83 & 0.04 & .82 \\
$\mathrm{FiO}_{2}$ & -0.05 & .76 & -0.13 & .39 \\
$\mathrm{PCO}_{2}{ }^{*}$ & -0.38 & .14 & -0.18 & .50 \\
Duration of ORS & -0.08 & .59 & 0.02 & .90 \\
PICU length of stay & -0.13 & .38 & 0.08 & .59 \\
\hline
\end{tabular}

ORS, overall respiratory support, including high flow nasal cannula, noninvasive ventilation, and invasive ventilation.

Values are Pearson` or Spearman correlation coefficients.

\begin{tabular}{|c|c|c|c|}
\hline & IMV/NIV ( $n=16)$ & HFNC $(n=28)$ & $\boldsymbol{P}$ \\
\hline Weight, $g$ & $4010(3304-4550)$ & $4435(3725-5900)$ & .02 \\
\hline Age, d & $35(21-55)$ & $39(18-75)$ & .88 \\
\hline RR (breath/min) & $68(57-79)$ & $65(54-80)$ & .29 \\
\hline HR (beat $/ \mathrm{min}$ ) & $154(138-163)$ & $153(140-162)$ & .87 \\
\hline $\mathrm{SpO}_{2}(\%)$ & $94.5(92.0-97.0)$ & $95.0(92.5-99.0)$ & .43 \\
\hline $\mathrm{FiO}_{2}(\%)$ & $21.0(21.0-29.0)$ & $24.5(21.0-30.0)$ & .74 \\
\hline m-WCAS & $2.75(2.0-3.5)$ & $2.50(2.0-3.0)$ & .68 \\
\hline Silverman-Andersen score & $3(2-5)$ & $2(1-3)$ & .14 \\
\hline $\mathrm{pH}$ & 7.39 (7.37-7.39) & $7.36(7.31-7.42)$ & .74 \\
\hline $\mathrm{PCO}_{2}(\mathrm{~mm} \mathrm{Hg})$ & $50(47-59)$ & $47(40-53)$ & .24 \\
\hline PTIF (L/min) & $6.90(5.00-9.00)$ & $7.50(4.35-10.65)$ & .39 \\
\hline PTIF (L/kg/min) & $1.62(1.46-2.07)$ & $1.57(1.16-2.07)$ & .47 \\
\hline $\mathrm{TV}(\mathrm{mL})$ & $22(17-28)$ & $23(17-29)$ & .29 \\
\hline $\mathrm{Ti}(\mathrm{s})$ & $0.32(0.28-0.42)$ & $0.33(0.29-0.38)$ & .68 \\
\hline $\mathrm{Te}(\mathrm{s})$ & $0.38(0.32-0.55)$ & $0.43(0.33-0.61)$ & .14 \\
\hline
\end{tabular}

$I M V$, invasive mechanical ventilation; $M A B P$, mean arterial blood pressure; NIV, noninvasive ventilation; $T e$, expiratory time; $T i$, inspiratory time. 


\begin{tabular}{|c|c|c|c|c|}
\hline & PTIF & $P$ & Weight-indexed PTIF & $P$ \\
\hline$H R^{*}$ & 0.11 & .47 & 0.26 & .09 \\
\hline $\mathrm{RR}^{*}$ & -0.13 & .38 & 0.14 & .37 \\
\hline m-WCAS & 0.16 & .31 & 0.02 & .88 \\
\hline Silverman-Andersen score & 0.04 & .83 & 0.04 & .82 \\
\hline $\mathrm{FiO}_{2}$ & -0.05 & .76 & -0.13 & .39 \\
\hline $\mathrm{PCO}_{2}{ }^{*}$ & -0.38 & .14 & -0.18 & .50 \\
\hline Duration of ORS & -0.08 & .59 & 0.02 & .90 \\
\hline PICU length of stay & -0.13 & .38 & 0.08 & .59 \\
\hline
\end{tabular}

ORS, overall respiratory support, including high flow nasal cannula, noninvasive ventilation, and invasive ventilation.

Values are Pearson* or Spearman correlation coefficients.
Table III. Clinical and spirometric data in infants requiring IMV or NIV and infants exclusively supported with HFNC

\begin{tabular}{|c|c|c|c|}
\hline & IMV/NIV $(n=16)$ & HFNC $(n=28)$ & $\boldsymbol{P}$ \\
\hline Weight, $\mathrm{g}$ & $4010(3304-4550)$ & $4435(3725-5900)$ & .02 \\
\hline Age, d & $35(21-55)$ & $39(18-75)$ & .88 \\
\hline RR (breath/min) & $68(57-79)$ & $65(54-80)$ & .29 \\
\hline HR (beat/min) & $154(138-163)$ & $153(140-162)$ & .87 \\
\hline $\mathrm{SpO}_{2}(\%)$ & $94.5(92.0-97.0)$ & $95.0(92.5-99.0)$ & .43 \\
\hline $\mathrm{FiO}_{2}(\%)$ & $21.0(21.0-29.0)$ & $24.5(21.0-30.0)$ & .74 \\
\hline m-WCAS & $2.75(2.0-3.5)$ & $2.50(2.0-3.0)$ & .68 \\
\hline Silverman-Andersen score & $3(2-5)$ & $2(1-3)$ & .14 \\
\hline $\mathrm{pH}$ & 7.39 (7.37-7.39) & $7.36(7.31-7.42)$ & .74 \\
\hline $\mathrm{PCO}_{2}(\mathrm{~mm} \mathrm{Hg})$ & $50(47-59)$ & $47(40-53)$ & .24 \\
\hline PTIF (L/min) & $6.90(5.00-9.00)$ & $7.50(4.35-10.65)$ & .39 \\
\hline PTIF (L/kg/min) & $1.62(1.46-2.07)$ & $1.57(1.16-2.07)$ & .47 \\
\hline TV $(\mathrm{mL})$ & $22(17-28)$ & $23(17-29)$ & .29 \\
\hline $\mathrm{Ti}(\mathrm{s})$ & $0.32(0.28-0.42)$ & $0.33(0.29-0.38)$ & .68 \\
\hline Te (s) & $0.38(0.32-0.55)$ & $0.43(0.33-0.61)$ & .14 \\
\hline
\end{tabular}

$I M V$, invasive mechanical ventilation; $M A B P$, mean arterial blood pressure; NIV, noninvasive ventilation; $T e$, expiratory time; $T i$, inspiratory time. 